\title{
Late Cenozoic continuous aridification in the western Qaidam Basin: evidence from sporopollen records
}

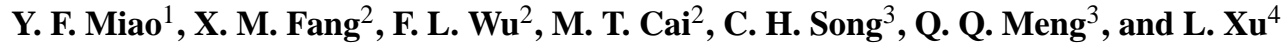 \\ ${ }^{1}$ Key Laboratory of Desert and Desertification, Cold and Arid Regions Environmental and Engineering Institute, \\ Chinese Academy of Sciences, Lanzhou, 730000, China \\ ${ }^{2}$ Key Laboratory of Continental Collision and Plateau Uplift, Institute of Tibetan Plateau Research, \\ Chinese Academy of Sciences, Beijing, 100085, China \\ ${ }^{3}$ School of Earth Science, Lanzhou University, Lanzhou, 730000, China \\ ${ }^{4}$ Qinghai Petroleum Sub-corporation of Petro China Company Limited, Dunhuang, 736202, China
}

Correspondence to: X. M. Fang (fangxm@itpcas.ac.cn)

Received: 3 February 2013 - Published in Clim. Past Discuss.: 21 March 2013

Revised: 19 June 2013 - Accepted: 2 July 2013 - Published: 9 August 2013

\begin{abstract}
Cenozoic climate changes in inner Asia provide a basis for understanding linkages between global cooling, the Tibetan Plateau uplift, and possibly the development of the East Asian monsoon. Based on a compilation of palynological results from the western Qaidam Basin, this study reconstructed a 15-million-year (Ma) record of changing vegetation and paleoclimates spanning the middle Miocene to present (comprising two series: $\sim 18-5 \mathrm{Ma}$ and $\sim 3.1-0 \mathrm{Ma}$, respectively). The thermophilic percentages were highest between 18 and $14 \mathrm{Ma}$, and decreased after $14 \mathrm{Ma}$, closely corresponding to the Middle Miocene Climatic Optimum (MMCO) between 18 and $14 \mathrm{Ma}$ and the following global climatic cooling between 14 and $5 \mathrm{Ma}$. At the same time, decreases in the xerophytic and coniferous taxa percentages, and the increasing logarithmic ratio of non-arboreal pollen to arboreal pollen (ln (NAP/AP)), reveal the continuous aridification across both the basin and surrounding mountains. Between $\sim 3.1$ and $0 \mathrm{Ma}$, the percentages of the thermophilic, xerophytic and coniferous pollen as well as the $\ln$ (NAP/AP) imply further cooling and drying in this region since 3.1 Ma. We argue that these vegetation and climate patterns during the late Cenozoic western Qaidam Basin are primarily a result of the global cooling, with the Tibetan Plateau uplift and East Asian summer monsoon having contributions of lesser importance.
\end{abstract}

\section{Introduction}

Central Asia experienced generally dry conditions during the late Oligocene-early Miocene period, in contrast to East Asia where humid conditions are thought to indicate the key period in the development of the modern-like arid and Asian monsoon climates (e.g., Wang, 1984; Liu et al., 1998; Sun and Wang, 2005; Zhang and Guo, 2005; Guo et al., 2008). Since the mid-Cenozoic, the evolution of climate near the boundary of Central Asia and East Asia has influenced the wind-blown sediment characteristics and the vegetation history. Hence, studies of both the wind-blown silt sediments (loess and red clay) deposited in Central Asia (e.g., Liu, 1985; Ding et al., 1992; Sun et al., 1998; An et al., 2001; Guo et al., 2002; Qiang et al., 2011) and the vegetation history (e.g., Jiang and Ding, 2008; Sun and Zhang, 2008; Hui et al., 2011; Miao et al., 2011; Tang et al., 2011; Zhang and Sun, 2011) can provide information about the environmental changes and driving forces influencing the landscape and climate. However, reconstructions of some dramatic events and even of the longer term climatic trends can vary between different climate proxies (e.g., Ma et al., 1998, 2005; Sun and Zhang, 2008; Kent-Corson et al., 2009; Tang et al., 2011; Zhuang et al., 2011). For example, eolian sediments suggest enhanced aridity at 5.3 Ma in the Tarim Basin (Sun and Liu, 2006), whereas pollen records show a humid phase during the same period in the neighboring Tian Shan Mountains (Sun et al., 2007). Accordingly, two basic theories have 
been proposed with regard to climatic influences: (i) that climate responded primarily to a stepwise uplift of the Tibetan Plateau following the India-Asia collision and associated tectonic events, which altered the atmospheric circulation (e.g., Manabe and Terpstra, 1974; Kutzbach et al., 1989; Ruddiman and Kutzbach, 1989; Manabe and Broccoli, 1990; Raymo and Ruddiman, 1992; An et al., 2001; Liu et al., 2003) and initiated rapid silicate weathering (e.g., Edmond and Huh, 1997; Wan et al., 2012), while the global cooling only played a secondary role; and (ii) global cooling reduced the amount of the precipitation and the effective moisture, and the Tibetan Plateau uplift was less important (e.g., Lu et al., 2010; Miao et al., 2011, 2012; Tang et al., 2011). Although the retreat of the shallow Paratethys Sea has also been identified as an important factor in the decreasing precipitation in Central Asia (Ramstein et al., 1997; Zhang et al., 2007), this seems to have occurred before the late Cenozoic (Bosboom, et al., 2011).

The first key step in addressing these uncertainties is to determine better the characteristics of the climatic trends by obtaining high-quality climate records. The Qaidam Basin in central Inner Asia (north of the Tibetan Plateau) provides a key location to explore climate changes, where the effects of the global temperature, Tibetan Plateau uplift and development of the Asian monsoon are preserved due to the basin's ideal location and super-thick Cenozoic sediments (e.g., Rieser et al., 2005; Fang et al., 2007; Wang et al., 2007; Lu and Xiong, 2009; Miao et al., 2011, 2012; Wu et al., 2011; Cai et al., 2012; Chang et al., 2012) (Fig. 1a). This study compiles pollen results from the western Qaidam Basin to reveal the aridification patterns and trends, and then discusses the associated mechanisms.

\section{Geological setting}

The Qaidam Basin, with an average elevation of $\sim 2900 \mathrm{~m}$ and area of $\sim 120000 \mathrm{~km}^{2}$, is the largest intermontane basin at the northeastern edge of the Tibetan Plateau. The basin is surrounded by the Altyn Tagh Mountains to the northwest, the Qilian Mountains to the northeast, and the Kunlun Mountains to the south (Fig. 1b). In modern times, the climate in the Qaidam Basin has been mainly controlled by westerlies, while the Asian summer monsoon usually extends only to the southeastern part of the basin. The basin's mean annual temperature (MAT) lies between $2{ }^{\circ} \mathrm{C}$ and $4{ }^{\circ} \mathrm{C}$, and the mean annual precipitation (MAP) is below $100 \mathrm{~mm}$ in most parts of the basin (less than $25 \mathrm{~mm}$ in the western part), but reaches $150-200 \mathrm{~mm}$ at the southeastern margin of the basin because of the long-range influence of the Asian summer monsoon during summer (Du and Sun, 1990). The mean annual evaporation exceeds the MAP by more than 20 times, leading to a temperate, arid-type climate (Zhou et al., 1990). Deserts (including the Gobi) and salt lakes are the main features of the basin today.
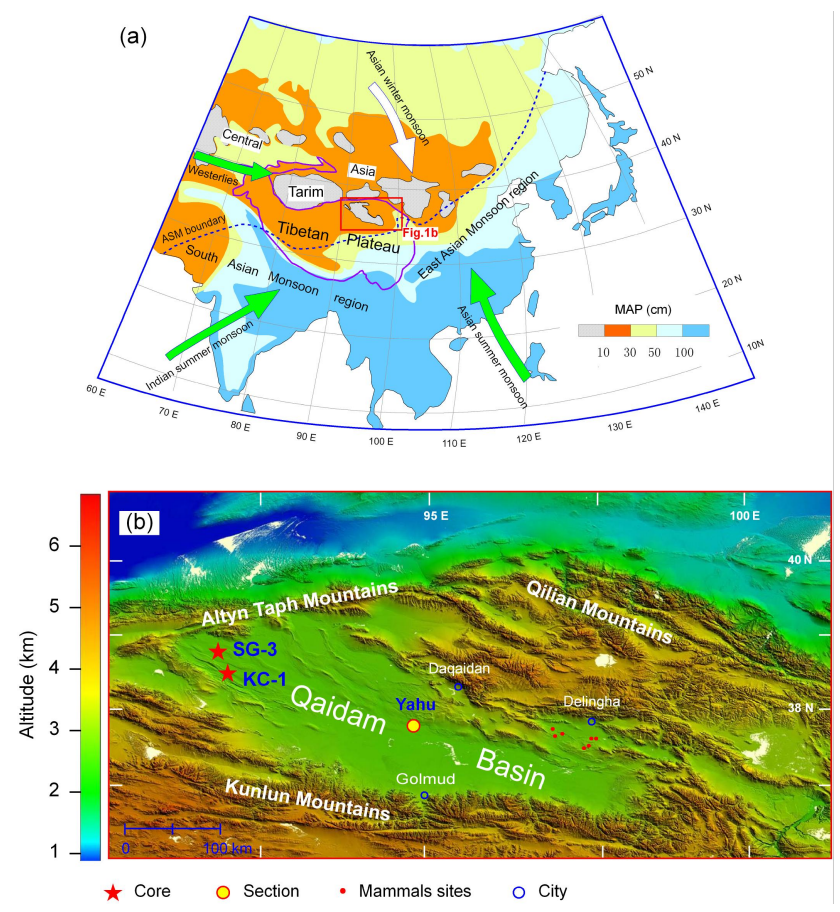

Fig. 1. (a) Physical geography and distribution of mean annual precipitation (MAP) in Asia and main precipitation sources influencing the Qaidam Basin (ASM: modern Asian summer monsoon, after Gao, 1962), and (b) digital elevation map of the Qaidam Basin, showing the locations of the KC-1 (Miao et al., 2011) and SG-3 (Cai et al., 2012) pollen cores; Yahu pollen section (Wu et al., 2011); and mammal sites used for isotopic studies in the eastern Qaidam Basin (C. F. Zhang et al., 2012).

Work by petroleum geologists over the last $50 \mathrm{yr}$ has established a basin-wide lithostratigraphic framework for the Qaidam Basin. Throughout the basin, seven formations (Fm) have been defined (from the lowest, upward): the Lulehe Fm, the Xia Ganchaigou Fm, the Shang Ganchaigou (SGCG) Fm, the Xia Youshashan (XYSS) Fm, the Shang Youshashan (SYSS) Fm, the Shizigou (SZG) Fm, and the Qigequan (QGQ) Fm. Seismic profiles show good lithostratigraphic correlations and comparability of the different horizons throughout the entire basin (e.g., Gu et al., 1990; Huang et al., 1996; Xia et al., 2001; Rieser et al., 2005, 2006; Zhou et al., 2006). Several geologists have identified and studied numerous animal fossils (e.g., Wang et al., 2007; Chang et al., 2008; C. F. Zhang et al., 2012) or have provided paleomagnetic dating (e.g., Sun et al., 2005; Fang et al., 2007; Lu and Xiong, 2009; Chang et al., 2012; W. L. Zhang et al., 2012, 2013) in this basin.

This paper reports the analysis of two cores: KC-1 and SG-3. The depth of the KC-1 core reaches $3435 \mathrm{~m}$, passing through the bottom of the SZG Fm, the entire SYSS Fm, and ending just into the upper part of the XYSS Fm (Fig. 2). The ages of the KC-1 core cover $\sim 18 \mathrm{Ma}$ to $5 \mathrm{Ma}$ (see details in Miao et al., 2011). A paleomagnetic study of the SG-3 boring 


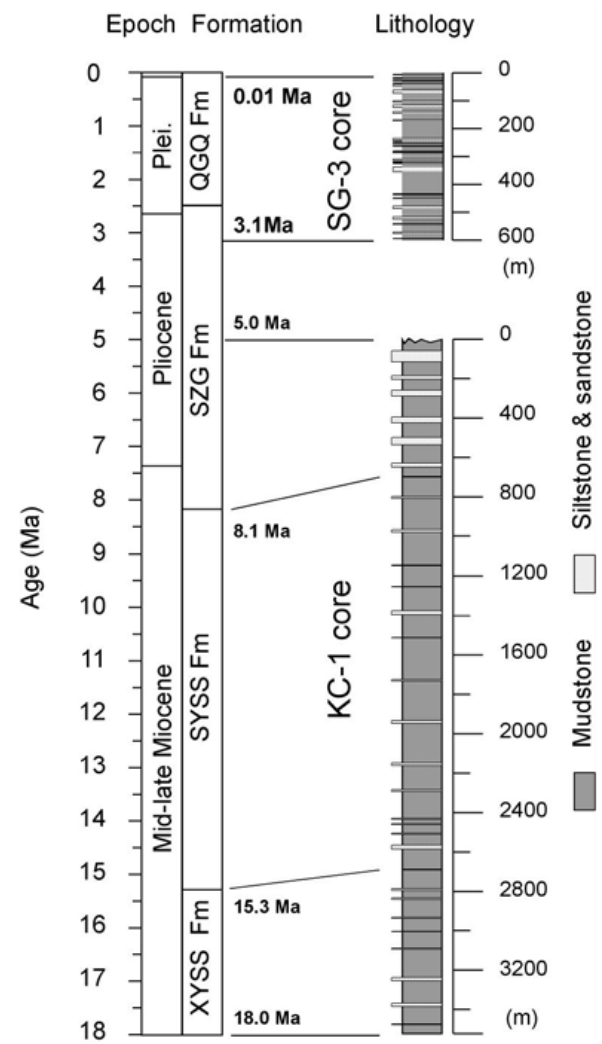

Fig. 2. Late Cenozoic stratigraphic distribution in the KC-1 (Miao et al., 2011) and SG-3 (Cai et al., 2012) cores.

(drilled to a depth of $600 \mathrm{~m}$ ) indicates that it covers the age range between 3.1 and $0 \mathrm{Ma}$ (for details, see Cai et al., 2012). In total, the ages of these two cores cover from $\sim 18 \mathrm{Ma}$ to $0 \mathrm{Ma}$, with a gap of 1.9 million years between 5 and $3.1 \mathrm{Ma}$.

\section{Data and methods}

A total of 58 and 103 samples were taken from the KC1 and SG-3 sites, respectively, for palynological analysis. In both cores, more than 300 pollen grains per sample were identified in order to obtain the detailed palynomorph content of each sample. In the $\mathrm{KC}-1$ core, the coniferous pollen taxa dominated most of the samples; Picea, Pinus, Podocarpaceae, Tsuga, Cedrus and Taxodiaceae/Cupressaceae/Taxaceae (TCT) were identified in all pollen slides. The other most common pollen taxa came from terrestrial shrubs and herbs (TSH), such as Chenopodiaceae, Ephedraceae, Asteraceae, Artemisia, Nitraria, Poaceae, etc. In comparison, the diversity and abundances of broad-leaved pollen taxa like Quercus, Juglandaceae, Ulmaceae and Betulaceae were much lower. Only a few types of algae and fungal spores were found in some samples (Miao et al., 2011). Meanwhile, in the SG-3 core, the sporopollen taxa primarily comprised TSH: Artemisia, Chenopodiaceae, Poaceae,
Asteraceae, Ephedraceae and Nitraria (the average of the sum of all these herbs and shrubs was $94.0 \%$ ); the trees Picea, Abies, Pinus, Betulaceae, Ulmaceae, Quercus and Juglandaceae were of secondary importance with low percentages (average $6.0 \%$ ). A few pteridophyte and algal spores were also found (Cai et al., 2012).

Although distinct pollen zones in the cores have been identified and discussed, as of yet there has been no detailed comparison, proper statistical analysis or combination between cores. In this study, we used the Tilia software (E. Grimm of Illinois State Museum, Springfield, Illinois, USA) to plot pollen diagrams. Next, we used detrended correspondence analysis (DCA) and principle component analysis (PCA) to identify the pollen ecologic similarities, and finally we discuss the long-term vegetation history and its driving forces.

\section{Results and analysis}

In both cores we reconstructed the pollen diagram in the same taxa order using any taxa that occurred in at least two samples with a relative abundance of $>1 \%$ in either core. This allowed easy comparison of percentage changes (Figs. 3 and 4). Stratigraphically constrained cluster analysis (CONISS) yielded two distinct zones (periods) in the KC-1 core, as follows.

(1) Zone KC-1-I: between 3435 and $2360 \mathrm{~m}$ (corresponding to approx. 18-14 Ma), showing a high abundance of alpine Cedrus, Tsuga, Podocarpaceae and Pinus, but low Picea, while TSH taxa such as Nitraria and Artemisia exhibited low abundances and Ephedraceae was relatively high. (2) Zone KC-1-II: between 2300 and $50 \mathrm{~m}$ (approx. 14-5 Ma), all TSH showed increasing percentages, while the conifers decreased except for Picea, which steadily increased until $\sim 9 \mathrm{Ma}$ and then slightly decreased (Fig. 3).

In the SG-3 cores, again two periods could be identified based on the CONISS. In Zone SG-3-I (between 600 and $346 \mathrm{~m}, 3.1-1.2 \mathrm{Ma}$ ), the TSH were dominant and characterized by high percentages of Chenopodiaceae (average (av.) $\sim 30 \%$ ), Artemisia (av. $\sim 33 \%$ ) and Ephedraceae (av. $\sim 10 \%$ ), while tree percentages were low. In Zone SG3-II (between 346 and $0 \mathrm{~m}, 1.2-0 \mathrm{Ma}$ ), TSH percentages continuously increased and were characterized by higher Chenopodiaceae (av. $\sim 34 \%$ ), Artemisia (av. $\sim 30 \%$ ) and Ephedraceae (av. $\sim 14 \%$ ), while trees continued to decline (Fig. 4). At the northwestern margin of the Qaidam Basin, pollen retrieved from Sugan Lake indicates sustained dry and cold conditions in the late Holocene (2.7 ka to today), following the end of the Pleistocene (K. Zhang et al., 2012).

In previous studies of the $\mathrm{KC}-1$ core, we divided the pollen diagram into five parts based on traditional analysis (variations in the abundance of the dominant taxa); however, in Fig. 3 the pollen diagram is clearly divided into two parts such that the former boundaries identified at ca. 17.0, 15.5, 14 and $8 \mathrm{Ma}$ by Miao et al. (2011) are now the 


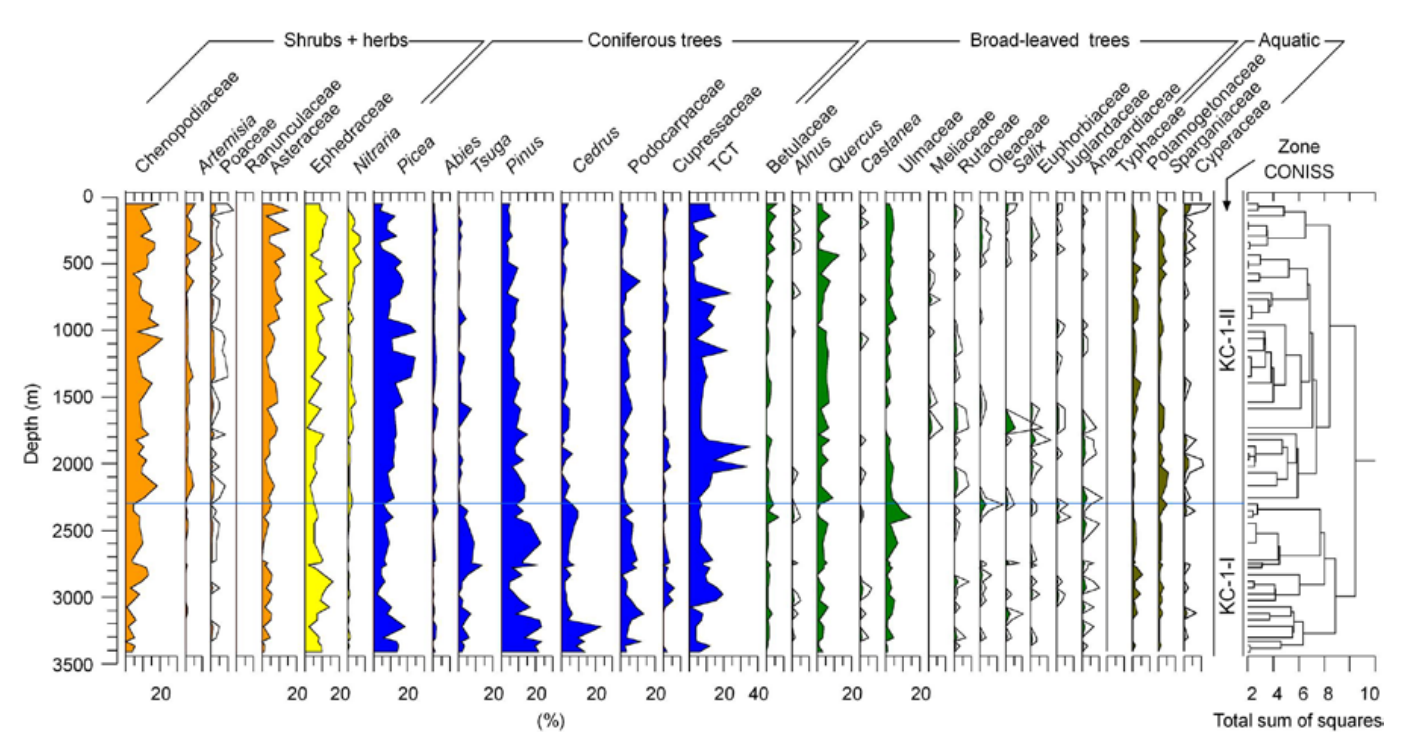

Fig. 3. KC-1 core pollen diagram in the western Qaidam Basin adapted from Miao et al. (2011) (TCT: Taxodiaceae/Cupressaceae/Taxaceae).

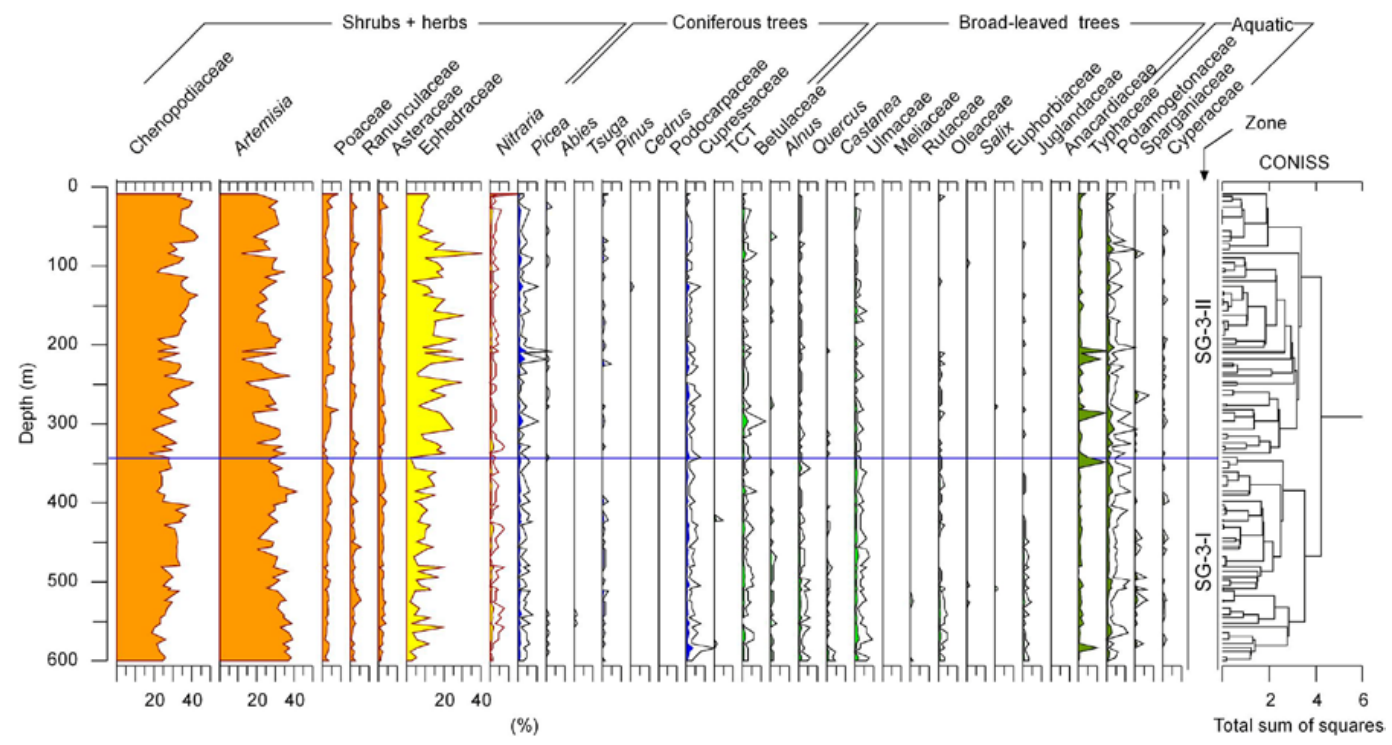

Fig. 4. SG-3 core pollen diagram in the western Qaidam Basin adapted from Cai et al. (2012) (TCT: Taxodiaceae/Cupressaceae/Taxaceae).

sub-boundaries at best. This means that only the boundary at $14 \mathrm{Ma}$ is significant relative to the others. Similar results for the SG-3 core yielded a boundary at $1.2 \mathrm{Ma}$, which is better defined than the others at 2.6, 1.8, 0.9 and 0.6 Ma (Cai et al., 2012).

In summary, when the two cores are analyzed together, we find the following characteristics. During 18-14 Ma, arboreal pollen taxa had the highest percentage (approx. $70 \%$ ) and were dominated by conifers (ca. $60 \%$, including Tsuga, Podocarpaceae, Cedrus and Pinus, etc.), while the TSH taxa (such as Chenopodiaceae, Asteraceae, Ephedraceae and $\mathrm{Ni}$ traria) were lowest (approx. 12\%). During 14-5 Ma, the vegetation experienced a relatively long-term deterioration, characterized by increasing TSH and decreasing conifers, although Podocarpaceae, Cedrus and Tsuga occurred frequently. Meanwhile, broad-leaved arbors (such as Quercus, Betulaceae, Ulmaceae, Juglandaceae, etc.) remained at roughly the same low levels (about 10-5\%). The early period of the Pliocene (5-3.1 Ma) remains unknown due to a lack of pollen data, but the vegetation has suffered even harsher conditions since $3.1 \mathrm{Ma}$, such that almost all conifers have disappeared: especially Pinaceae and Podocarpaceae. In the broad-leaved trees, no subtropical taxa were found and the deciduous arbors have continuously decreased $(\sim 10-1.4 \%)$. Meanwhile, TSH percentages have generally remained high (approx. 90\%) (Fig. 5). Overall, the compiled pollen data 


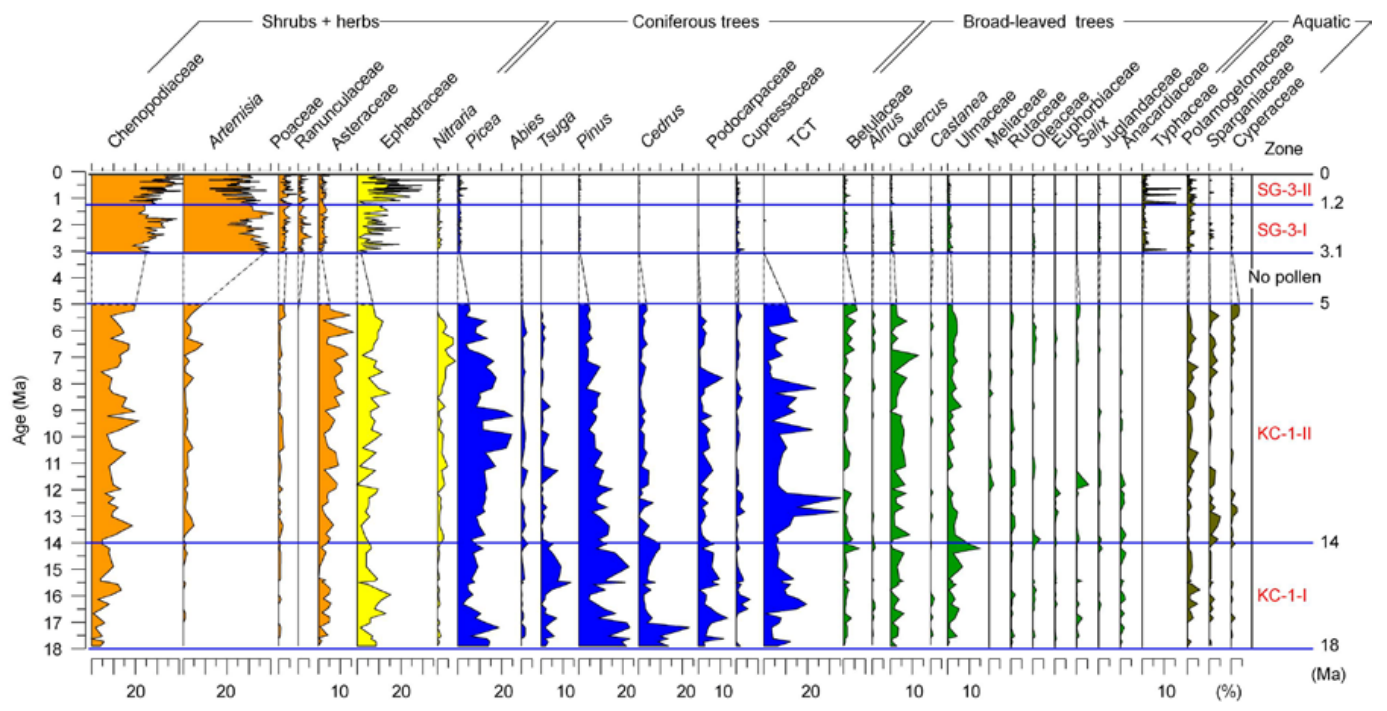

Fig. 5. Late Cenozoic pollen diagram with zones of the KC-1 and SG-3 cores (TCT: Taxodiaceae/Cupressaceae/Taxaceae).

show a continued expansion in TSH in contrast to decreasing arbors (including coniferous and broad-leaved trees) (Fig. 5).

In order to assess the pollen ecological similarities, 25 pollen taxa with percentages $>2 \%$ in any one sample were selected for detrended correspondence analysis (DCA) and principle components analysis (PCA) using the program CANOCO (ter Braak, 1988). Firstly, DCA was used to identify the length of the environmental gradient and to determine whether linear- or unimodal-based techniques should be employed in subsequent ordination analyses. The length of the gradient was 2.14 standard deviation units, suggesting linear techniques were most appropriate for our data (Birks, 1998). To summarize the data structure, PCA of the pollen assemblages was performed (Fig. 6).

PCA of the pollen samples (Fig. 6a) and pollen taxa (Fig. 6b) reflects the characteristics of the pollen diagram and summarizes the main vegetation shifts. PCA axis 1 accounts for $70.3 \%$ of variability, and mostly reflects the relative change in TSH (Ephedraceae, Chenopodiaceae, Artemisia and others) on the left side and in trees (both the coniferous and broad-leaved taxa) on the right side; PCA axis 2 only accounts for $4.7 \%$, and no clear significance was identified due to its much lower contribution. The variations in sample scores represent shifts in four pollen zones and vegetation types, characterized by four separated clusters (Fig. 6a). For example, the loosely clustered zone KC-1-I and KC-1-II samples were characterized by high percentages of the conifers (such as Pinus, Tsuga, Cedrus, Podocarpaceae, Picea, and TCT), whereas zones SG-3-I and SG-3-II were characterized by high percentages of Artemisia, Chenopodiaceae, Poaceae and Ephedraceae (Fig. 6b). PCA axis 1 mostly separates zones of the KC-1 core from those of the SG-3 core.
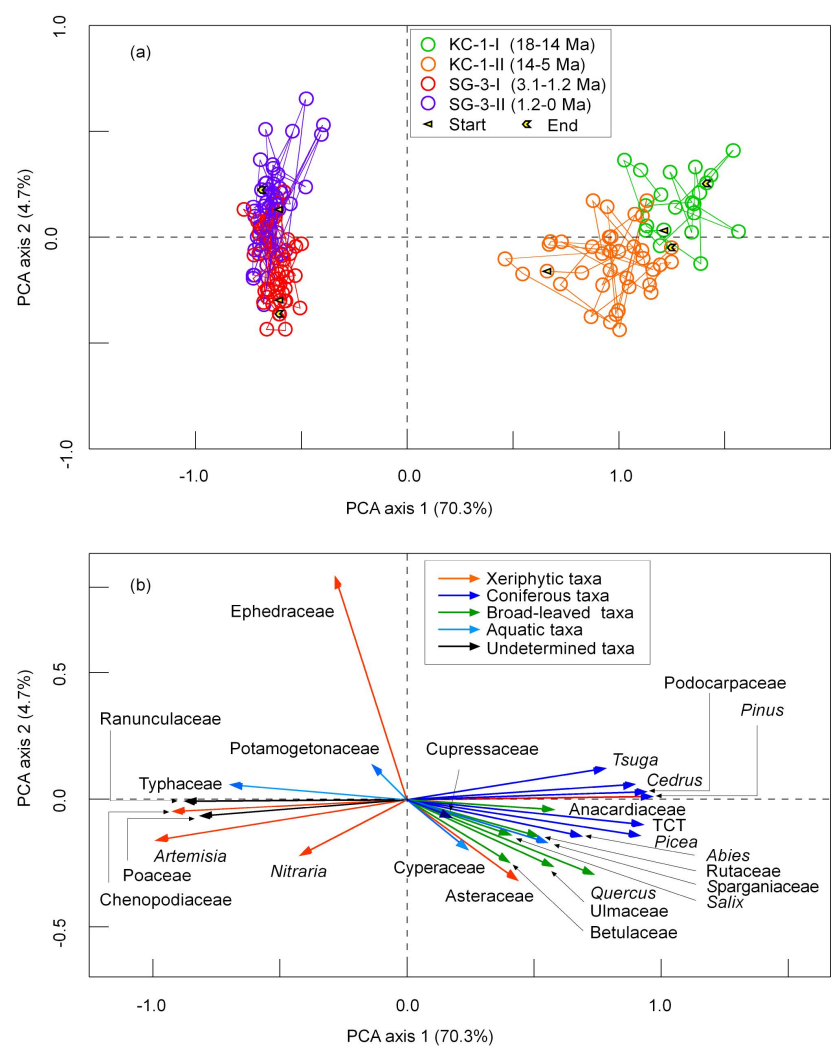

Fig. 6. PCA plot of (a) pollen samples, with pollen zones indicated in the KC-1 and SG-3 cores in the western Qaidam Basin ("Start" and "End" represent the first and last samples, respectively, in each zone), and (b) pollen types (the end of the arrow indicates the score values of PCA axes 1 and 2; TCT: Taxodiaceae/Cupressaceae/Taxaceae). 


\section{Discussion}

Today, almost all conifers belong to the alpine elements: for example, Podocarpaceae grows mainly in the subtropical southern Asian mountains under a warm and humid climate at elevations between 800 and $1000 \mathrm{~m}$. In contrast to the Podocarpaceae, Tsuga also prefers humid conditions in mountainous regions, but experiences its maximum growth between 2800 and $3200 \mathrm{~m}$ and tolerates a cooler climate. $\mathrm{Ce}$ drus tolerates warm and humid conditions, although it needs less precipitation than Podocarpaceae and Tsuga. Picea tolerates low temperatures and (depending of the species) less precipitation (Florin, 1963), and thrives at elevations between 2300 and $4200 \mathrm{~m}$. Pinus, however, adapts to a wide range of temperature and precipitation conditions in Asia and occurs over a relatively wide elevation range of $1300-4200 \mathrm{~m}$ (Florin, 1963; Wu, 1995). Cupressaceae mainly grows on sunny slopes between 1700 and $5300 \mathrm{~m}$. Due to an unclear relationship (or distribution), the preferred environment of TCT is uncertain.

The broad-leaved trees are mainly distributed in the humid to semi-humid East Asia in relatively low-lying areas, since the Rutaceae, Euphorbiaceae, Sapindaceae and Anacardiaceae usually need a warmer (subtropical) environment than the temperate deciduous taxa such as Betulaceae, Quercus, Castanea, Ulmaceae, Meliaceae, Oleaceae, Salix and Juglandaceae (Wu, 1995).

In contrast to the alpine flora and broad-leaved trees, the TSH group, including Ephedraceae, Chenopodiaceae, $\mathrm{Ni}$ traria, Asteraceae and Artemisia, inhabits mainly arid and semi-arid regions of northwestern China, and is defined as "xerophytic flora". Besides the TSH, other taxa (such as Typhaceae, Potamogetonaceae, Sparganiaceae and Cyperaceae) mainly inhabit water and are defined as "aquatic plants". PCA shows that the trends in Typhaceae and Potamogetonaceae are opposite to those of the Cyperaceae and Sparganiaceae (Fig. 6b). Highly variable individual percentages yet low averages are possibly the key reason for their opposing PCA directions (Fig. 5). A similar pattern was found for Poaceae and Ranunculaceae, both of which are widely distributed and cannot be regarded as true xerophytic taxa in this study, although their scores are similar to those of typical xerophytic taxa.

Pollen assemblages containing high proportions of xerophytic taxa and humid alpine conifers, as well as low percentages of the broad-leaved and aquatic pollen, indicate an open, dry area (e.g., basins, plains or plateaus) surrounded by an alpine region that is relatively wet due to the topographic influence. In the arid to semiarid regions, broad-leaved trees usually inhabit relatively wet areas and are therefore confined to a narrow range, in contrast to the conifers and xerophytic taxa, but sometimes they can also reach the open areas along the rivers (e.g., Miao et al., 2011; Wu et al., 2011). The aquatic taxa can only depend on the water-covered area.
In summary, the pollen and PCA results from the western Qaidam Basin reveal four major changes in vegetation over the last 18 million years. From 18 to $14 \mathrm{Ma}$, the coniferous flora grew in the alpine zone and the relatively sparse xerophytic flora were found in the basin. During 14-5 Ma, the coniferous flora retreated and xerophytic flora expanded continuously (Figs. 3 and 5). However, during 3.1-1.2 Ma, the steppe flora expanded greatly and coniferous forest almost disappeared. In the following period (1.2-0 Ma), the steppe flora spread further (Figs. 4 and 5).

\subsection{Aridification and temperature trends}

As a result of these floral associations, the interactions between xerophytic flora and alpine flora can be used as ideal proxies for the paleoclimate development in the Qaidam Basin. To illustrate this relationship, Fig. 7 plots the degree of aridity in the basin (represented by the xerophytic taxa, defined as the sum of Chenopodiaceae, Ephedraceae, $\mathrm{Ni}$ traria, Artemisia and Asteraceae, Fig. 7a) and the humidity of the alpine zone (represented by all conifers, Fig. 7b) in the Qaidam Basin. The increase of the xerophytic percentages from about $\sim 12 \%$ to $\sim 80 \%$ (Fig. $7 \mathrm{a}$ ), and the decrease of the total conifers from about $\sim 70 \%$ to $\sim 2 \%$ (Fig. $7 b$ ) between $\sim 18$ and $5 \mathrm{Ma}$ and between 3.1 and $0 \mathrm{Ma}$ support continuous aridification in the western Qaidam Basin during that time period. The decreasing logarithmic ratio of non-arboreal pollen to arboreal pollen (ln (NAP/AP)), which ranged between -1.5 and 4.2 , followed a similar pattern to the aridification trends (Fig. 7c).

Overall, time series of the xerophytic, alpine and coniferous percentages, and $\ln (\mathrm{NAP} / \mathrm{AP})$ indicate a continuous drying process in both the basins and surrounding alpine regions.

At the same time, the PCA results did not yield any temperature information. Here we select Podocarpaceae, Anacardiaceae, Euphorbiaceae, Rutaceae, Meliaceae and Sapindaceae in the KC-1 core as the thermophilic taxa, mainly owing to their modern relationships with the subtropical region ( $\mathrm{Wu}, 1995)$. The total percentage of this group reveals the continuous cooling trend during $18-5 \mathrm{Ma}$ (Fig. 7d). During 3.1-0 Ma, when the thermophilic taxa in the KC-1 core had disappeared, Cai et al. (2012) replaced the thermophilic taxa by the cumulative percentages of Betula, Quercus, Castanea and Juglans in the SG-3 core due to their relatively warmer habitat preference than the widely eurythermal but dry-tolerant shrubs and herbs; these data support further cooling (Fig. 7d). All correlations between thermophilic $(\%)$ and xerophytic (\%), conifers (\%), and $\ln (\mathrm{NAP} / \mathrm{AP})$ are strong (Fig. 8a, b and c). 


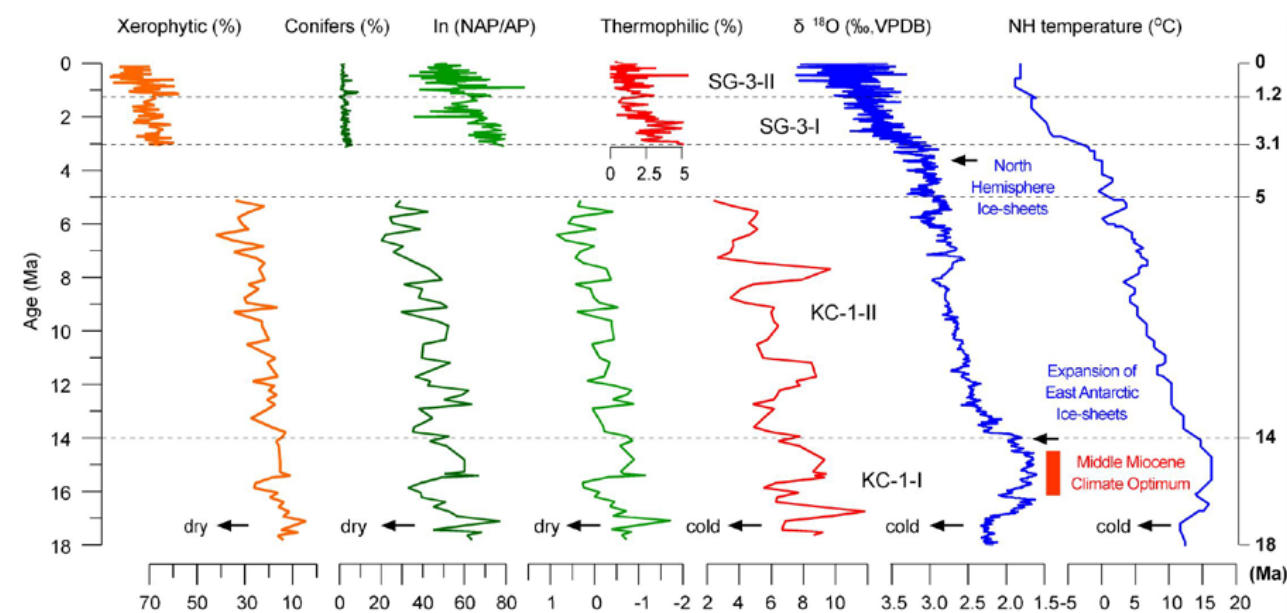

(a)

(b)

(c)

(d)

(e)

(f)

Fig. 7. Comparison of (a) xerophytic percentages, (b) conifer percentages, (c) ln (NAP/AP) (NAP: non-arboreal pollen; AP: arboreal pollen) and (d) thermophilic element percentages, with (e) the global deep-sea oxygen isotope $\left(\delta^{18} \mathrm{O} \%\right.$ ) records (20-point running average) (Zachos et al., 2008) and (f) temperature simulations using a 1-D ice-sheet model (de Boer et al., 2010).

\subsection{Global cooling and Tibetan Plateau uplift}

All records from the two sites show continuous drying and cooling since the middle Miocene. The following important basic scientific question is the following: what controlled the aridification of the western Qaidam Basin during the late Cenozoic - was it dominated by global cooling or by an uplift of the Tibetan Plateau?

Figure 7 includes the global deep-sea oxygen isotope records (e.g., Miller et al., 1987; Zachos et al., 2001, 2008) and temperature simulations with a 1-D ice-sheet model (de Boer et al., 2010) to show the Earth's late Cenozoic global temperature evolution. As shown in Fig. 7e, the global climate (reported by the averaged $\delta^{18} \mathrm{O}$ values) shifted from about $2.2 \%$ at $18 \mathrm{Ma}$, to $\sim 1.7 \%$ o between $17 \mathrm{Ma}$ and $14 \mathrm{Ma}$, but then to $\sim 3 \%$ at $3 \mathrm{Ma}$. Values have now increased to over $\sim 4 \%$, indicating an overall cooling trend since the Middle Miocene Climatic Optimum (Zachos et al., 2008). Temperature simulations with a 1-D ice-sheet model show as much as a $15^{\circ} \mathrm{C}$ cooling in the Northern Hemisphere (de Boer et al., 2010) (Fig. 7f). Temperature changes in the western Qaidam Basin indicated by the thermophilic percentages clearly parallel those temperature changes indicated by both the $\delta^{18} \mathrm{O}$ and 1-D ice-sheet model. Correlation between the thermophilic (\%) and $\delta^{18} \mathrm{O}$ values is still strong (Fig. 8d).

In addition to the similar $\delta^{18} \mathrm{O}$ trends, four other aspects support the suggestion that the cooling since $18 \mathrm{Ma}$ in the western Qaidam Basin may have been controlled by worldwide global cooling.

First, the thermophilic percentages correlate well with the oxygen isotope curve; for example, between approx. 18 and $14 \mathrm{Ma}$, the thermophilic percentages (from $\sim 3 \%$ to $\sim 12 \%$ ) show an increase roughly coincident with the
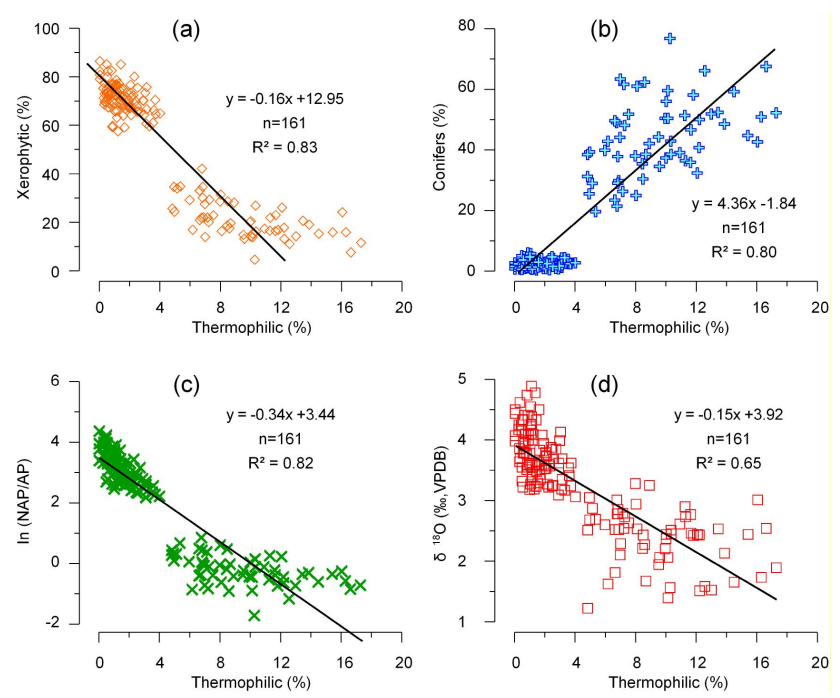

Fig. 8. Correlation between (a) xerophytic percentages and thermophilic percentages, (b) coniferous percentages and thermophilic percentages, (c) $\ln$ (NAP/AP) and thermophilic percentages, and (d) $\delta^{18} \mathrm{O} \%$ o (data from Zachos et al., 2008) and thermophilic percentages.

Middle Miocene Climatic Optimum (MMCO; Zachos et al., 2008). At the same time, the xerophytic percentages fall to their lowest values (between $\sim 5 \%$ and $\sim 15 \%$, average $12 \%)$. From $14 \mathrm{Ma}$ until $5 \mathrm{Ma}$, the thermophilic percentages continuously decreased (from $\sim 8 \%$ to $\sim 2 \%$ ) coincident with the global cooling, while the xerophytic percentages increased from $\sim 15 \%$ to $\sim 30 \%$. Based on the pollen records for 3.1-0 Ma, the thermophilic percentages compare fairly well with both the cooling trend and the glacial-interglacial 
cycles indicated by oceanic $\delta^{18} \mathrm{O}$ data. The strong correlation between the thermophilic (\%) and $\delta^{18} \mathrm{O}$ values supports such relationships (Fig. 8d).

Second, the precipitation (moisture) reaching inner Asia firstly has to cross Europe, high-latitude Asia, the East Asian monsoon region, or the South Asian monsoon region, which means that the precipitation in the Qaidam Basin should follow a similar trend to that in one or all four of these regions (e.g., Miao et al., 2012). Notably, most records from these four regions have shown drying and cooling trends during the Miocene (e.g., Europe: Mosbrugger et al., 2005; Utescher et al., 2007; Jiménez-Moreno et al., 2010; high-latitudes: White et al., 1997; East Asia and South Asia: Quade et al., 1989, 1995; Wang et al., 2001; Clift, 2006; Clift et al., 2008; Passey et al., 2009; Wan et al., 2010). In the western Qaidam Basin, the long-term trends of xerophytic percentages, coniferous percentages and $\ln$ (NAP/AP) covering 18-5 Ma and 3.1$0 \mathrm{Ma}$ further support this model.

Third, many studies have found relationships between temperature and the atmospheric vapor capacity. For example, Oard (1990) established a relationship between the water vapor capacity and temperature. Normally, high precipitation requires relatively rapid evaporation of sea water, which only occurs from warm water because water evaporation increases exponentially with temperature (Oard, 1990) (Fig. 9a). This can explain well the general precipitation trend as a function of latitude for the present day: specifically, the reduction in precipitation as temperature decreases (except in the subtropical high belt between $20^{\circ}$ and $40^{\circ}$ latitude) (Fig. 9b). So, the western Qaidam Basin aridification and cooling trends can be explained by Oard's (1990) model and the global precipitation pattern: during the warm Miocene (18-14 Ma), increased precipitation could fall in the Qaidam Basin due to the higher water vapor capacity (Fig. 9a), similarly to the abundant precipitation in low latitudes (Fig. 9b). Consequently, precipitation has decreased as a result of global cooling during 14-5 and 3.1-0 Ma and the corresponding reduction in water vapor capacity (Fig. 9a), similarly to the lower precipitation in the high latitudes (Fig. 9b). Such clear relationships can also explain the climatic trends in Eurasia (e.g., Lu et al., 2010; Tang et al., 2011; Miao et al., 2011) and the Asian monsoonal region (e.g., Quade et al., 1989, 1995; Passey et al., 2009).

Fourth, the global cooling would have lowered the upper timberline. For example, on the Tibetan Plateau, Picea can reach 2300 to $4200 \mathrm{~m}$ above sea level; however, in the Tian Shan Mountains, it can only grow below $2800 \mathrm{~m}$ due to falling temperatures. All other arbors have also experienced a similar upper timberline retreat with temperature, which means that in the western Qaidam Basin, all arboreal percentages should decline as the climate cools and their suitable habitat shrinks. The related pollen percentages will continuously decrease until their eventual disappearance, whereas the xerophytic taxa percentages have increased (Fig. 7a and b, also shown as Fig. 10a and c).
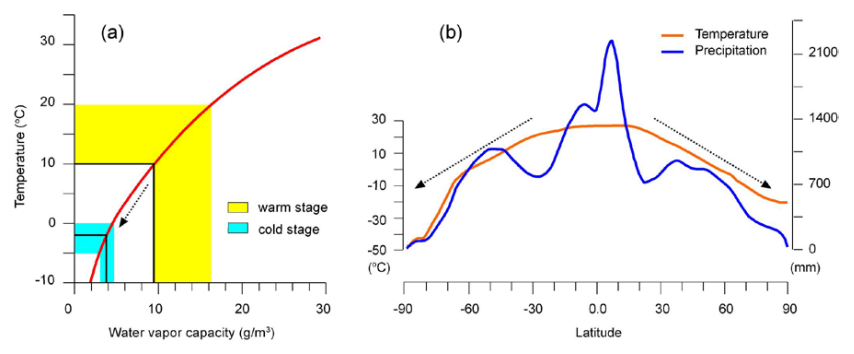

Fig. 9. Plots showing (a) water vapor capacity at saturation $(11 \%$ relative humidity) versus temperature (Oard, 1990) (note the $60 \%$ drop in capacity as temperature decreases from 10 to $-2{ }^{\circ} \mathrm{C}$ (black line); highlighted areas show the vapor capacity in the warm Miocene (yellow) and cold Pleistocene (blue) according to de Boer et al. (2010) (arrow showing the exponential relationship between cooling and water vapor capacity reduction), and (b) variations in MAT and MAP as a function of latitude for the present day (Haywood et al., 2000) (arrow indicating the general relationship between cooling and precipitation reduction).

As an alternative to global cooling, many models support the assumption that rapid Tibetan Plateau uplift has caused the strong drying of Inner Asia (e.g., Manabe and Terpstra, 1974; Kutzbach et al., 1989; Ruddiman and Kutzbach, 1989; Manabe and Broccoli, 1990; Raymo and Ruddiman, 1992; Liu et al., 2003; Zhang et al., 2007). This would mean that orogenesis could have effectively disturbed precipitation patterns in the mountainous regions of Central Asia (especially the Tibetan Plateau) as it underwent various extensive phases of orogeny.

In the western Qaidam Basin, rich Picea and other species in Pinaceae, as well as Podocarpaceae and TCT together, form the vertical vegetational bands in the mountains, in contrast to the dry basin occupied by the xerophytic taxa. So, we believe the vertical topography should have existed during the Miocene. However, it is very difficult to directly separate the paleoaltimetry information, and even uplift events, from the pollen results. For example, in the SG-3 core, the pollen assemblage shifts at approx. 2.6 Ma, $1.2 \mathrm{Ma}, 0.9 \mathrm{Ma}$, and $0.6 \mathrm{Ma}$ can be explained by Tibetan Plateau uplift as well as global cooling (Cai et al., 2012) but without any direct evidence. In the eastern Qaidam Basin, based on the enamel $\delta^{13} \mathrm{C}$ and $\delta^{13} \mathrm{O}$ records (Fig. 10b and d), C. F. Zhang et al. (2012) noted that the obvious aridification since the early Pliocene was likely due to the combined effects of regional tectonism and global cooling, but lacked tectonism records. So, we only can infer results for the tectonics based on records from the basin and surrounding area.

Firstly, tectonic evidence reveals some tectonic events at 3.6 Ma (W. L. Zhang et al., 2013), 3.2 Ma (Chang et al., 2012), 2.6-2.2 Ma, 1.1 Ma (W. L. Zhang et al., 2013) and $<0.8 \mathrm{Ma}$ (W. L. Zhang et al., 2012) in this region (Fig. 10e). The eastern part of the Qaidam Basin shows some evidence of tectonic activity at about $\sim 14.7$ Ma (Fang et al., 2007), 


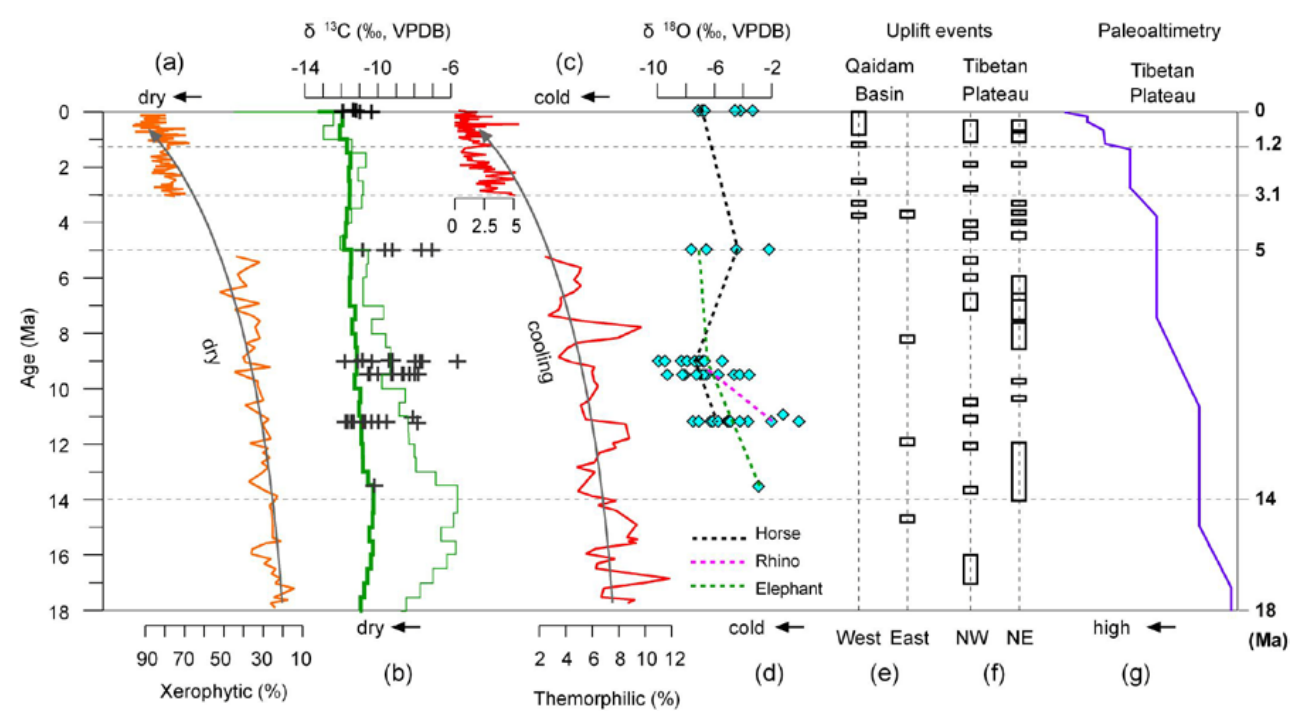

Fig. 10. Compiled aridification records in the (a) western (this study) and (b) eastern Qaidam Basin (black cross: $\delta^{13} \mathrm{C}$ records of bulk enamel samples by C. F. Zhang et al. (2012); coarse green line: averaged $\delta^{13} \mathrm{C}$ records of model-predicted values for animals with pure C3 diets by Passey et al. (2009); thin green line at five times the coarse green line), temperature in the (c) western (this study) and (d) eastern Qaidam Basin (blue diamonds: $\delta^{18} \mathrm{O}$ records from bulk enamel samples after C. F. Zhang et al., 2012), tectonic uplift events in (e) the Qaidam Basin (rectangle showing the tectonic events; the western basin after Chang et al., 2012, and W. L. Zhang et al., 2012, 2013; the eastern basin after Fang et al., 2007, and Lu and Xiong, 2009) and (f) the northern Tibetan Plateau (rectangles showing the tectonic events; the NW part after Zheng et al., 2000; Chen et al., 2002; Wang et al., 2003; Sun et al., 2004, 2005, 2007, 2008, 2009; Charreau et al., 2005, 2006; Huang et al., 2006; Heermance et al., 2007, 2008; Sun and Zhang, 2008; Tang et al., 2011, and Zhang and Sun, 2011; the NE part after Li et al., 1997; C. H. Song et al., 2001; Y. G. Song et al., 2001; Zhao et al., 2001; Fang et al., 2003, 2005a, b; Pares et al., 2003; Zheng et al., 2006; Lin et al., 2010; Wang et al., 2010; and W. T. Wang et al., 2011; X. X. Wang et al., 2011), and (g) the presumed paleoaltimetry history after An et al. (2006).

$\sim 12 \mathrm{Ma}$ (Lu and Xiong, 2009), $\sim 8.1 \mathrm{Ma}$ and $\sim 3.6 \mathrm{Ma}$ (Fang et al., 2007) (Fig. 10e). Looking more widely, we have summarized the timing and signature of tectonic uplifts near, at some distance or far from the surrounding mountains (e.g., Li et al., 1997; Zheng et al., 2000, 2006; C. H. Song et al., 2001; Y. G. Song et al., 2001; Chen et al., 2002; Fang et al., 2003, 2005a, b; Pares et al., 2003; Wang et al., 2003; Sun et al., 2004, 2005, 2007, 2008, 2009; Charreau et al., 2005, 2006; Huang et al., 2006; Heermance et al., 2007, 2008; Sun and Zhang, 2008; Lin et al., 2010; Wang et al., 2010; W. T. Wang et al., 2011; X. X. Wang et al., 2011; Tang et al., 2011; Zhang and Sun, 2011; Nie et al., 2013) (Fig. 10f). Figure $10 \mathrm{~g}$ also shows an interpretation of the Tibetan Plateau elevation history during the late Cenozoic based on compiled multiple geological records (An et al., 2006).

The above studies suggest that uplift events have become more frequent with time. If this is indeed true, our results of aridification and temperature trends should have been influenced by the tectonic uplifts, especially in the latest period, because the tectonic events can influence climate and vegetation patterns by altering the precipitation (e.g., Miao et al., 2012; Z. G. Zhang et al., 2013). For example, in the SG-3 core, the pollen assemblage shifts at approx. $2.6 \mathrm{Ma}, 1.2 \mathrm{Ma}$, $0.9 \mathrm{Ma}$ and $0.6 \mathrm{Ma}$ appear to have been responses to the Tibetan Plateau uplift in addition to the global cooling (Cai et al., 2012). In the eastern Qaidam Basin, the timing of aridification mainly after the early Pliocene has also been linked to tectonic events.

In addition to tectonics, paleoaltimetry caused by the tectonics is another important aspect influencing the aridity. However, much evidence shows that the Tibetan Plateau reached its modern height during the Oligocene or Eocene (Rowley, 2007; Garzione, 2008; Quade et al., 2011) or most likely between 30 and $20 \mathrm{Ma}$ (Wu et al., 2008). In this case, the Qaidam Basin probably remained stable during the late Cenozoic; thus the aridification of the Qaidam Basin would have been less closely linked with the Tibetan Plateau uplift according to the models (e.g., Manabe and Terpstra, 1974; Kutzbach et al., 1989; Manabe and Broccoli, 1990; Raymo and Ruddiman, 1992; Liu et al., 2003). However, considering the several tectonic events and stratigraphic deformation history (Liu et al., 2009; Wang et al., 2012) within the basin, and the series of tectonic events on the northern Tibetan Plateau, we argue that the Qaidam Basin might have experienced upwards growth during the late Cenozoic even though an exact paleoaltimetry history cannot be established, which would have intensified aridification.

Additional considerations include the influence of the retreat of the shallow Paratethys (Ramstein et al., 1997; Zhang et al., 2007) or topographic teleconnections (e.g., C. F. Zhang 
et al., 2012; Bosboom et al., 2011). However, the Paratethys is thought to have mostly retreated from the Tarim Basin before the Miocene (e.g., Bosboom et al., 2011), suggesting no direct relationship with the late Cenozoic period currently under discussion. For the topographic teleconnections, the aridification of the eastern Qaidam Basin since the early Pliocene is successfully explained by the result of the more effective barrier preventing moisture from the Indian Ocean or Bay of Bengal from reaching the basin; if such a barrier did exist, it should also have influenced the western Qaidam Basin to some extent.

\subsection{Asian monsoon}

In Asia, the compilation of paleobotanical and lithological data from all over China has revealed that the Miocene Asian monsoon boundary was very close to the eastern Qaidam Basin (Liu et al., 1998; Guo et al., 2002, 2008; Sun and Wang, 2005). Theoretically, the climate in the Qaidam Basin could be influenced by the retreat or expansion of the Asian monsoon; the closer the region to the boundary, the stronger effect the monsoon has. However, it is very difficult to separate effects of the Asian monsoon from those of the global cooling, especially as evidence has now shown that the Asian monsoon intensity also decreased during the global cooling (e.g., Jiang and Ding, 2008; Passey et al., 2009; Miao et al., 2012). Some alternative conclusions have also been presented (e.g., Ding et al., 1992; An et al., 2001), and Oard's (1990) model can also explain the relationship between the Asian summer monsoon strength and global cooling (e.g., Clift, 2006; Wan et al., 2007, 2010; Clift et al., 2008; Passey et al., 2009): the Asian monsoon should have expanded in the early Miocene due to higher water vapor contents under higher temperatures. Thus, the western Qaidam Basin may have been influenced by the monsoonal system, as evidenced by the many wet taxa found during that time, including Podocarpaceae and Tsuga. With the reducing monsoon strength, the monsoon boundary shifted away from the western basin, but the eastern part might have remained in the monsoon system until the early Pliocene according to records from the eastern Qaidam Basin (C. F. Zhang et al., 2012).

Hence, we consider that the long-term aridification trends during the late Cenozoic ( 18-5 Ma, and 3.1-0 Ma) western Qaidam Basin have been mainly driven by global cooling, with a lesser influence from the Tibetan Plateau uplift and Asian monsoon.

\subsection{Aridification during 5-3.1 Ma}

There are no pollen data for reconstructing climate during the period 5-3.1 Ma in the western Qaidam Basin: was there a step change or a continuous decrease? The answer to this question will strongly impact the quality of the correlation between our signals and the global climate. Wu et al. (2011)

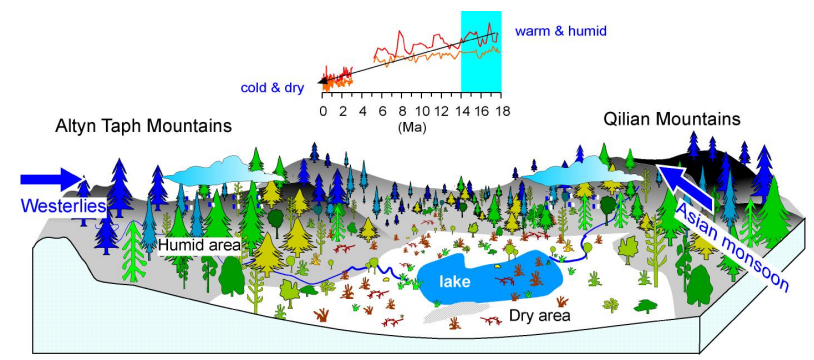

(a) 18-14 Ma: relatively warm \& wet

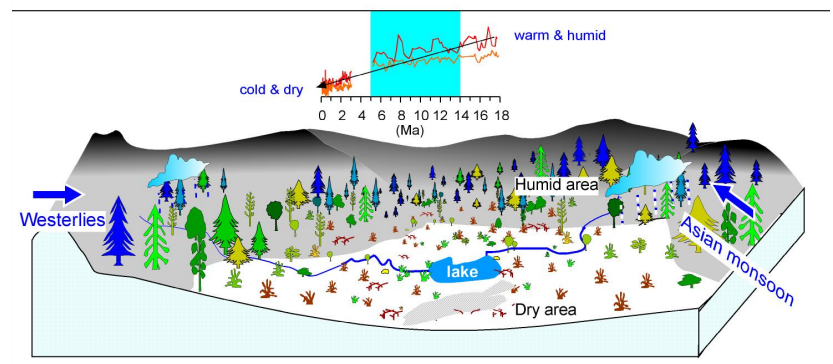

(b) 14-5 Ma: relatively cold \& dry

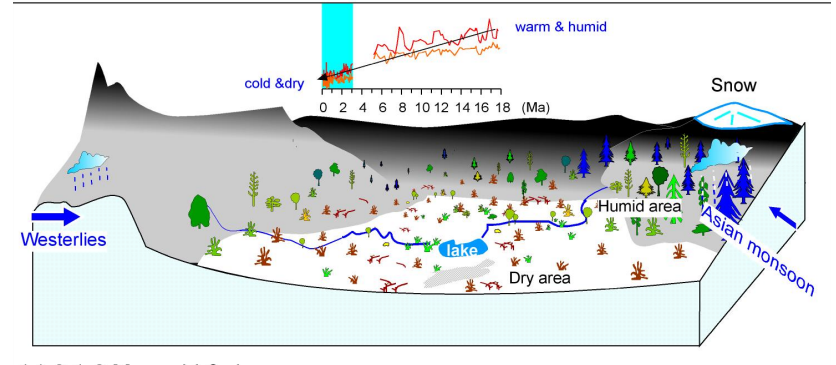

(c) 3.1-0 Ma: cold \& dry

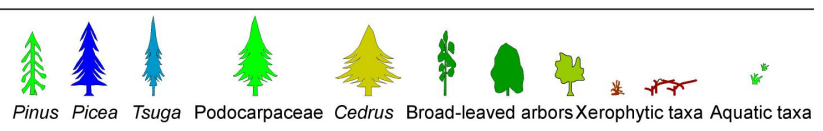

Fig. 11. Cartoon illustrating the vegetation, paleoclimates, and paleoaltimetry of the Qaidam Basin during (a) 18-14 Ma, (b) 14-5 Ma, and (c) 3.1-0 Ma (blue rectangle showing the corresponding climate background according to the compiled pollen results).

constructed a pollen diagram for the outcropping lacustrine Yahu section in the central Qaidam basin covering 5.31.8 Ma. These pollen results revealed much higher percentages of Picea, Pinus, Chenopodiaceae and Artemisia, which is obviously different from our compiled results (contemporaneous pollen from the KC-1 core: $5.3-5 \mathrm{Ma}$, and SG-3 core: $3.1-1.8 \mathrm{Ma}$ ), possibly due to more precipitation reaching this region than the western part. However, the pollen data in the Yahu section still show a long-term aridification trend in both the basin and surrounding mountains, with two small drying steps at $3.6 \mathrm{Ma}$ and $2.6 \mathrm{Ma}$; again, these are explained by both global cooling and uplift of the Tibetan Plateau (Wu et al., 2011). In the Yahu section, the dry conditions are also indicated by the extraordinarily thickboned fish (Chang et al., 2008). Very close to the KC-1 and SG-3 cores, the F2 core was also used for collecting pollen (Wang et al., 1999), and while there were few pollen samples 
and unclear pollen percentages except for Pinus, Picea, and Podocarpaceae, the aridification trends were similar to our compiled results (Wang et al., 1999), also reflecting a longterm drying trend.

Figure 11 illustrates the relationships between the vegetation, climate and topographic history, as a cartoon picture. During the middle Miocene (18-14 Ma), relatively sparse steppe taxa grew in what was probably a low-lying basin. The alpine trees, including Tsuga, Picea, Podocarpaceae and Pinus, flourished on the surrounding mountains, utilizing the rich precipitation during a global warm stage (possibly from the Asian summer monsoon and westerlies). At this time, the basin and surrounding mountains were relatively low (Fig. 11a). During the late Miocene and early Pliocene (14$5 \mathrm{Ma}$ ), the area covered by xerophytic taxa increased, and the alpine trees declined as less rain reached the basin. Then, the basin and mountains were uplifted (Fig. 11b). During the latest Pliocene and Pleistocene (3.1-0 Ma), xerophytic taxa almost completely replaced the conifers, due to the further global cooling, and the basin probably reached its modern elevation (Fig. 11c).

\section{Conclusions}

The Qaidam Basin is the largest basin on the northern margin of the Tibetan Plateau, and has experienced an arid climate during our study period. Our study compiled pollen results from two cores in order to characterize the aridification process, spanning the periods of 18-5 Ma and 3.1-0 Ma with a gap during 5-3.1 Ma. During this extended time period, the xerophytic percentages increased, conifers decreased, and the logarithmic ratio of non-arboreal pollen to arboreal pollen increased. These results suggest a general drying process in the Qaidam region, including both the basin and surrounding mountains. The thermophilic percentages correspond well with the oxygen isotope data, thereby linking local conditions with the global climatic cooling. The Tibetan Plateau uplift and the Asian summer monsoon strength exerted secondary influences.

Further pollen research should address three aims: coring the sediments representing 5-3.1 Ma, identifying more samples in the $\mathrm{KC}-1$ core, and collecting pollen at those fossil mammal sites in the eastern basin, in order to better understand the complete vegetation and climate changes, the differences between the different parts of the basin, and the dominating mechanisms influencing the changes.

Acknowledgements. This work was co-supported by the Strategic Priority Research Program of the Chinese Academy of Sciences (Grant No. XDB03020103, XDB03020402), the (973) National Basic Research Program of China (Grant No. 2013CB956400, 2011CB403000, 2010CB833401), and NSFC Grants (40920114001, 41021001, 41172153, 41272184). We thank
D. Mildenhall, C. Jaramillo, J. Nie, and an anonymous reviewer for giving suggestions, plus Bill Isherwood for help with improvement of the English.

Edited by: Y. Godderis

\section{References}

An, Z. S., Kutzbach, J. E., Prell, W. L., and Porter, S. C.: Evolution of Asian monsoons and phased uplift of the Himalaya-Tibetan Plateau since Late Miocene times, Nature, 411, 62-66, 2001.

An, Z. S., Zhang, P. Z., Wang, E. C., Wang, S. M., Qiang, X. K., Li, L., Song, Y. G., Chang, H., Liu, X. M., Zhou, W. J., Liu, W. G., Cao, J. J., Li, X. Q., Shen, J., Liu, Y., and Ai, L.: Changes of the monsoon-arid environment in China and growth of the Tibetan Plateau since the Miocene, Quaternary Sci., 26, 678-693, 2006.

Birks, H. J. B.: Numerical tools in palaeolimnology-Progress, potentialities, and problems, J. Paleolimnol., 20, 307-332, 1998.

Bosboom, R. E., Dupont-Nivet, G., Houben, A. J. P., Brinkhuis, H., Villa, G., Mandic, O., Stoica, M., Zachariasse, W. J., Guo, Z., Li, C., and Krijgsman, W.: Late Eocene sea retreat from the Tarim Basin (west China) and concomitant Asian paleoenvironmental change, Palaeogeogr. Palaeocl., 299, 385-398, 2011.

Cai, M. T., Fang, X. M., Wu, F. L., Miao, Y. F., and Appel, E.: Pliocene-Pleistocene stepwise drying of Central Asia: evidence from paleomagnetism and sporopollen record of the deep borehole SG-3 in the western Qaidam Basin, NE Tibetan Plateau, Global Planet. Change, 94-95, 72-81, 2012.

Chang, H., Ao, H., An, Z. S., Fang, X. M., Song, Y. G., and Qiang, X. K.: Magnetostratigraphy of the Suerkuli Basin indicates Pliocene (3.2 Ma) activity of the middle Altyn Tagh Fault, northern Tibetan Plateau, J. Asian Earth, 44, 169-175, 2012.

Chang, M. M, Wang, X. M., Liu, H., Miao, D., Zhao, Q., Wu, G., Liu, J., Li, Q., Sun, Z., and Wang, N.: Extraordinarily thickboned fish linked to the aridification of the Qaidam Basin (northern Tibetan Plateau), P. Natl. Acad. Sci. USA, 105, 1324613251, 2008.

Charreau, J., Chen, Y., Gilder, S., Dominguez, S., Avouacd, J. P., Sene, S., Sun, D. J., Li, Y. G., and Wang, W. M.: Magnetostratigraphy and rock magnetism of the Neogene Kuitun He section (northwest China): implications for Late Cenozoic uplift of the Tian Shan mountains, Earth Planet. Sc. Lett., 230, 177-192, 2005.

Charreau, J., Gilder, S., Chen, Y., Dominguez, S., Avouac, J. P., Sevket, S., Jolivet, M., Li, Y., and Wang, W.: Magnetostratigraphy of the Yaha section, Tarim Basin (China): 11 Ma acceleration in erosion and uplift of the Tian Shan mountains, Geology, 34, 181-184, 2006.

Chen, J., Burbank, D. W., Scharer, K. M., Sobel, E., Yin, J. H., Rubin, C., and Zhao, R. B.: Magnetochronology of the Upper Cenozoic strata in the southwestern Chinese Tian Shan: rates of Pleistocene folding and thrusting, Earth Planet. Sc. Lett., 195, 113-130, 2002.

Clift, P. D.: Controls on the erosion of Cenozoic Asia and the flux of clastic sediment to the ocean, Earth Planet. Sc. Lett., 241, 571580, 2006.

Clift, P. D., Hodges, K. V., Heslop, D., Hannigan, R., Long, H. V., and Calves, G.: Correlation of Himalayan exhumation rates and Asian monsoon intensity, Nat. Geosci., 1, 875-880, 2008. 
de Boer, B., van de Wal, R. S. W., Bintanja, R., Lourens, L. J., and Tuenter, E.: Cenozoic global ice-volume and temperature simulations with 1-D ice-sheet models forced by benthic $\delta^{18} \mathrm{O}$ records, Ann. Glaciol., 51, 23-33, 2010.

Ding, Z. L., Rutter, N. W., Han, J. T., and Liu, T. S.: A coupled environmental system formed at about 2.5Ma in East Asia, Palaeogeogr. Palaeocl., 94, 223-242, 1992.

Du, Q. and Sun, S. Z.: Vegetation in the Qaidam Basin region and its utilization, Science Press, Beijing, 6 pp., 1990.

Edmond, J. M. and Huh, Y.: Chemical weathering yields in hot and cold climates, in: Tectonic Uplift and Climate Change, edited by: Ruddiman, W. F. and Prell, W., Plenum Press, TS2, 329-351, 1997.

Fang, X. M., Garzione, C., VanderVoo, R., Li, J. J., and Fan, M. J.: A flexural subsidence by $29 \mathrm{Ma}$ on the NE edge of Tibet from the magnetostratigraphy of Linxia Basin. China, Earth Planet. Sc. Lett., 210, 545-560, 2003.

Fang, X. M., Yan, M. D., VanderVoo, R., Rea, D. K., Song, C. H., Pares, J. M., Nile, J. S., Gao, J. P., and Dai, S.: Late Cenozoic deformation and uplift of the NE Tibetan Plateau: evidence from high-resolution magnetostratigraphy of the Guide Basin, Qinghai Province, China. Geol. Soc. Am. Bull, 117, 1208-1225, 2005 a.

Fang, X. M., Zhao, Z. J., Li, J. J., Yan, M. D., Pan, B. T., Song, C. H., and Dai, S.: Magnetostratigraphy of the late Cenozoic Laojunmiao anticline in the northern Qilian Mountains and its implications for the northern Tibetan Plateau uplift, Sci. China Ser. D, 48, 1040-1051, 2005b.

Fang, X. M., Zhang, W. L., Meng, Q. Q., Gao, J. J., Wang, X. M., King, J., Song, C. H., Dai, S., and Miao, Y. F.: Highresolution magnetostratigraphy of the Neogene Huaitoutala section in the eastern Qaidam Basin on the NE Tibetan Plateau, Qinghai Province, China and its implication on tectonic uplift of the NE Tibetan Plateau, Earth Planet Sc. Lett., 258, 293-306, 2007.

Florin, R.: The distribution of conifer and taxad genera in time and space, Acta Horti Bergiani, 20, 121-312, 1963.

Gao, Y. X. (Ed.): On some problems of Asian monsoon, in: Some Questions about the East Asian Monsoon, Chinese Science Press, Beijing, 1-49, 1962.

Garzione, C. N.: Surface uplift of Tibet and Cenozoic global cooling, Geology, 36, 1003-1004, 2008.

Gu, S., Xu, W., Xue, C., Di, S., Yang, F., Di, H., and Zhao, D.: Regional Petroleum Geology of Qinghai-Xizang Oil-Gas Field, Vol. 14, Petroleum Publ. House, Beijing, 88 pp., 1990.

Guo, Z. T., Ruddiman, W. F., Hao, Q. Z., Wu, H. B., Qiao, Y. S., Zhu, R. X., Peng, S. Z., Wei, J. J., Yuan, B. Y., and Liu, T. S.: Onset of Asian desertification by $22 \mathrm{Myr}$ ago inferred from loess deposits in China, Nature, 416, 159-163, 2002.

Guo, Z. T., Sun, B., Zhang, Z. S., Peng, S. Z., Xiao, G. Q., Ge, J. Y., Hao, Q. Z., Qiao, Y. S., Liang, M. Y., Liu, J. F., Yin, Q. Z., and Wei, J. J.: A major reorganization of Asian climate by the early Miocene, Clim. Past, 4, 153-174, doi:10.5194/cp-4-1532008, 2008.

Haywood, A. M., Valdes, P. J., and Sellwood, B. W.: Global scale palaeoclimate reconstruction of the middle Pliocene climate using the UKMO GCM: initial results, Global Planet. Change, 25, 239-256, 2000.

Heermance, R. V., Chen, J., Burbank, D. W., and Wang, C. S.: Chronology and tectonic controls of Late Tertiary deposition in the southwestern Tian Shan foreland, NW China. Basin Res., 19, 599-632, 2007.

Heermance, R. V., Chen, J., Burbank, D. W., and Miao, J. J.: Temporal constraints and pulsed Late Cenozoic deformation during the structural disruption of the active Kashi foreland, northwest China, Tectonics, 27, TC6012-TC6039, 2008.

Huang, B. C., Piper, J. D. A., Peng, S. T., Liu, T., Li, Z., Wang, Q. C., and Zhu, R. X.: Magnetostratigraphic study of the Kuche Depression, Tarim Basin, and Cenozoic uplift of the Tian Shan Range, Western China, Earth Planet. Sc. Lett., 251, 346-364, 2006.

Huang, H. C., Huang, Q. H., and Ma, Y. S.: Geology of Qaidam and Petroleum Prediction, Geological Publ. House, Beijing, 257 pp., 1996.

Hui, Z. C., Li, J. J., Xu, Q. H., Song, C. H., Zhang, J., Wu, F. L., and Zhao, Z. J.: Miocene vegetation and climatic changes reconstructed from a sporopollen record of the Tianshui Basin, NE Tibetan Plateau, Palaeogeogr. Palaeocl., 308, 373-382, 2011.

Jiang, H. C. and Ding, Z. L.: A 20 Ma pollen record of EastAsian summer monsoon evolution from Guyuan, Ningxia, China, Palaeogeogr. Palaeocl., 265, 30-38, 2008.

Jiménez-Moreno, G., Suc, J. P., and Fauquette, S.: Miocene to Pliocene vegetation reconstruction and climate estimates in the Iberian Peninsula from pollen data, Rev. Palaeobot. Palynol., 162, 403-415, 2010.

Kent-Corson, M. L., Ritts, B. D., Zhuang, G. S., Bovet, P. M., Graham, S. A., and Chamberlain, C. P.: Stable isotopic constraints on the tectonic, topographic, and climatic evolution of the northern margin of the Tibetan Plateau. Earth. Planet. Sc. Lett., 282, 158-166, 2009.

Kutzbach, J. E., Guetter, P. J., Ruddiman, W. F., and Prell, W. L.: Sensitivity of climate to late Cenozoic uplift in southern Asia and the American west, numerical experiments, J. Geophys. Res., 94, 18393-18407, 1989.

Li, J. J., Fang, X. M., VanderVoo, R., Zhu, J. J., Niocaill, C. M., Cao, J. X., Zhong, W., Chen, H. L., Wang, J. L., Wang, J. M., and Zhang, Y. C.: Late Cenozoic magnetostratigraphy (11-0 Ma) of the Dong Shan ding and Wang Jia Shan sections in the Long Zhong Basin, western China, Geol. Mijnb, 76, 121-134, 1997.

Lin, X. B., Chen, H. L., Wyrwoll, K. H., and Cheng, X. G.: Commencing uplift of the Liupan Shan since 9.5 Ma: evidences from the Sikouzi section at its east side, J. Asina Earth Sci., 37, 350360, 2010.

Liu, D. L., Fang, X. M., Gao, J. P., Wang, Y. D., Zhang, W. L., Miao, Y. F., Liu, Y. Q., and Zhang, Y. Z.: Cenozoic stratigraphy deformation history in the central and eastern of Qaidam Basin by the balance section restoration and its implication, Acta Geol. Sin., 83, 359-371, 2009.

Liu, T. S.: Loess and the Environment, China Ocean Press, Beijing, $1-251,1985$.

Liu, T. S., Zheng, M. P., and Guo, Z. T.: Initiation and evolution of the Asian monsoon system timely coupled with the ice-sheet growth and the tectonic movements in Asian, Quaternary Sci. 3, 193-204, 1998.

Liu, X. D., Kutzbach, J. E., Liu, Z., An, Z. S., and Li, L.: The Tibetan Plateau as amplifier of orbital scale variability of the East Asian monsoon, Geophys. Res. Lett., 30, 1839, doi:10.1029/2003GL017510, 2003. 
Lu, H. J. and Xiong, S. F.: Magnetostratigraphy of the Dahonggou section, northern Qaidam Basin and its bearing on Cenozoic tectonic evolution of the Qilian Shan and Altyn Tagh Fault, Earth Planet. Sc. Lett., 288, 539-550, 2009.

Lu, H. Y., Wang, X., and Li, L.: Aeolian sediment evidence that global cooling has driven late Cenozoic stepwise aridification in central Asia, Geological Society, Special Publications, London, 342, 29-44, 2010.

Ma, Y. Z., Li, J. J., and Fan, X. M.: Pollen-based vegetational and climatic records during 30.6 to 5.0 My from Linxia area, Gansu, Chin. Sci. Bull., 43, 301-304, 1998.

Ma, Y. Z., Fang, X. M., Li, J. J., Wu, F. L., and Zhang, J.: The vegetation and climate change during Neocene and Early Quaternary in Jiuxi Basin, China, Science in China Ser. D, 48, 676-688, 2005.

Manabe, S. and Broccoli, A. J.: Mountains and arid climates of middle latitudes, Science, 247, 192-194, 1990.

Manabe, S. and Terpstra, T. B.: The effects of mountains on the general circulation of the atmosphere as identified by numerical experiments, J. Atmos. Sci., 31, 3-42, 1974.

Miao, Y. F., Fang, X. M., Herrmann, M., Wu, F. L., and Liu, D. L.: Miocene pollen record of $\mathrm{KC}-1$ core in the Qaidam Basin, NE Tibetan Plateau and implications for evolution of the East Asian monsoon, Palaeogeogr. Palaeocl., 299, 30-38, 2011.

Miao, Y. F., Herrmann, M., Wu, F. L., Yan, X. L., and Yang, S. L.: What controlled Mid-Late Miocene long-term aridification in Central Asia? - Global cooling or Tibetan Plateau uplift: a review, Earth-Sci. Rev., 112, 155-172, 2012.

Miller, K. G., Fairbanks, R. G., and Mountain, G. S.: Tertiary oxygen isotope synthesis, sea level history, and continental margin erosion, Paleoceanography, 2, 1-19, 1987.

Mosbrugger, V., Utescher, T., and Dilcher, D. L.: Cenozoic continental climatic evolution of central Europe, P. Natl. Acad. Sci. USA, 102, 14964-14969, 2005.

Nie, J. S., Song, Y. G., King, J. W., Zhang, R., and Fang, X. M.: Six million years of magnetic grain-size records reveal that temperature and precipitation were decoupled on the Chinese Loess Plateau during 4.5-2.6 Ma, Quaternary Res., 79, 465470, 2013

Oard, M. J.: An ice age caused by the Genesis Flood, El Cajon, California, Institute for Creation Research, 5 pp., 1990.

Pares, J. M., VanderVoo, R., Downs, W. R., Yan, M. D., and Fang, X. M.: Northeastward growth of the Tibetan Plateau: magnetostratigraphic insights from the Guide basin, J. Geophys. Res., 108, 1-11, 2003.

Passey, B. H., Ayliffe, L. K., Kaakinen, A., Zhang, Z., Eronen, J. T., Zhu, Y., Zhou, L., Cerling, T. E., and Fortelius, M.: Strengthened East Asian summer monsoons during a period of high-latitude warmth? Isotopic evidence from Mio-Pliocene fossil mammals and soil carbonates from northern China, Earth Planet. Sc. Lett., 277, 443-452, 2009.

Qiang, X. K., An, Z. S., Song, Y. G., Chang, H., Sun, Y. B., Liu, W. G., Ao, H., Dong, J. B., Fu, C. F., and Wu, F.: New Eolian red clay sequence on the western Chinese Loess Plateau linked to onset of Asian desertification about $25 \mathrm{Ma}$ ago, Sci. China Ser. D, 54, 136-144, 2011.

Quade, J., Cerling, T. E., and Bowman, J. R.: Development of Asian monsoon revealed by marked ecological shift during the latest Miocene in the northern Pakistan, Nature, 342, 163-166, 1989.
Quade, J., Cater, M. L. J., Ojha, P. T., Adam, J., and Harrison, M. T.: Late Miocene environmental change in Nepal and the northern Indian subcontinent: stable isotopic evidence from paleosols, Geol. Soc. Am. Bull., 107, 1381-1397, 1995.

Quade, J., Breecker, D. O., Daeron, M., and Eiler, J.: The paleoaltimetry of Tibet: an isotopic perspective, Am. J. Sci., 311, 77115, 2011.

Ramstein, G., Fluteau, F., Besse, J., and Joussaume, S.: Effect of orogeny, plate motion and land-sea distribution on Eurasian climate change over the past 30 million years, Nature, 386, 788795, 1997.

Raymo, M. E. and Ruddiman, W. F.: Tectonic forcing of late Cenozoic climate change, Nature, 359, 117-122, 1992.

Rieser, A., Neubauer, F., Liu, Y., and Ge, X.: Sandstone provenance of north-western sectors of the intracontinental Cenozoic Qaidam basin, western China: tectonic vs. climatic control, Sediment. Geol., 177, 1-18, 2005.

Rieser, A. B., Liu, Y., Genser, J., Neubauer, F., Handler, R., Friedl, G., and Ge, X. H.: 40Ar/39Ar ages of detrital white mica constrain the Cenozoic development of the intracontinental Qaidam Basin, China, Geol. Soc. Am. Bull., 118, 1522-1534, 2006.

Rowley, D. B.: Stable Isotope-based paleoaltimetry: theory and validation, Rev. Mineral. Geochem., 66, 23-52, 2007.

Ruddiman, W. F. and Kutzbach, J. E.: Forcing of the late Cenozoic uplift Northern Hemisphere climate by plateau uplift in the Southern Asia and American West, J. Geophys. Res., 94, 18409 18427, 1989.

Song, C. H., Fang, X. M., Li, J. J., Gao, J. P., and Fan, M. J.: Tectonic uplift and sedimentary evolution of the Jiuxi Basin in the northern margin of the Tibetan Plateau since 13 Ma BP, Sci. China Ser. D, 44, 92-202, 2001.

Song, Y. G., Fang, X. M., Li, J. J., An, Z. S., and Miao, X. D.: The late Cenozoic uplift of Liupan Shan, China, China Ser. D, 44, 176-184, 2001.

Sun, D. H., Shaw, J., An, Z. S., Cheng, M., and Yue, L.: Magnetostratigraphy and paleoclimatic interpretation of a continuous 7.2 Ma Late Cenozoic eolian sediments from the Chinese Loess Plateau, Geophys. Res. Lett., 25, 85-88, 1998.

Sun, J. M. and Liu, T. S.: The age of the Taklimakan Desert, Science, 312, 16-21, 2006.

Sun, J. M. and Zhang, Z. Q: Palynological evidence for the MidMiocene Climatic Optimum recorded in Cenozoic sediments of the Tian Shan Range, northwestern China, Global Planet. Change, 20, 53-68, 2008.

Sun, J. M., Zhu, R. X., and Bowler, J.: Timing of the Tian Shan Mountains uplift constrained by magnetostratigraphic analysis of molasses deposits, Earth Planet. Sc. Lett., 219, 239-253, 2004.

Sun, J. M., Zhu, R. X., and An, Z. S.: Tectonic uplift in the northern Tibetan Plateau since 13.7 Ma ago inferred from molasses deposits along the Altyn Tagh Fault, Earth Planet. Sc. Lett, 235, 641-653, 2005.

Sun, J. M., Xu, Q. H., and Huang, B. H.: Late Cenozoic magnetochronology and paleoenvironmental changes in the northern foreland basin of the Tianshan Mountains, J. Geophys. Res., 112, B04107, doi:10.1029/2006JB004653, 2007.

Sun, J. M., Zhang, L. Y., Deng, C. L., and Zhu, R. X.: Evidence for enhanced aridity in the Tarim Basin of China since 5.3 Ma, Quaternary Sci. Rev., 27, 1012-1023, 2008. 
Sun, J. M., Li, Y., Zhang, Z. Q., and Fu, B. H.: Magneostratigraphic data on the Neogene growth folding in the foreland basin of the southern Tianshan Mountains, Geology, 37, 1051-1054, 2009.

Sun, X. J. and Wang, P. X.: How old is the Asian monsoon system? palaeobotanical records from China, Palaeogeogr. Palaeocl., 222, 181-222, 2005.

Tang, Z. H., Ding, Z. L., White, P. D., Dong, X. X., Ji, J. L., Jiang, H. C., Luo, P., and Wang, X.: Late Cenozoic central Asian drying inferred from a palynological record from the northern Tian Shan, Earth Planet. Sc. Lett., 302, 439-447, 2011.

ter Braak, C. J. F.: CANOCO - a FORTRAN program for canonical community ordination, Technical Report LWA-88-02, GLW, Wageningen, 95 pp., 1988.

Utescher, T., Djordjevic-Milutinovic, D., Bruch, A. A., and Mosbrugger, V.: Climate and vegetation changes in Serbia during the last $30 \mathrm{Ma}$, Palaeogeogr. Palaeocl., 253, 141-152, 2007.

Wan, S. M., Li, A. C., Peter, D., Clift, J., and Stuut, W.: Development of the East Asian monsoon: mineralogical and sedimentologic records in the northern South China Sea since $20 \mathrm{Ma}$, Palaeogeogr. Palaeocl., 152, 37-47, 2007.

Wan, S. M., Clift, P. D., Li, A. C., Li, T. G., and Yin, X. Y.: Geochemical records in the South China Sea: implications for East Asian summer monsoon evolution over the last $20 \mathrm{Ma}$, Geol. Soc. London, 342, 245-263, 2010.

Wan, S. M., Clift, P. D., Li, A. C., Yu, Z. J., Li, T. G., and Hu, D. K.: Tectonic and climatic controls on long-term silicate weathering in Asia since $5 \mathrm{Ma}$, Geophys. Res. Lett., 39, L15611, doi:10.1029/2012GL052377, 2012.

Wang, J., Wang, Y. J., Liu, Z. C., Li, J. Q., and Xi, P.: Cenozoic environmental evolution of the Qaidam Basin and its implications for the uplift of the Tibetan Plateau and the drying of the central Asia, Palaeogeogr. Palaeocl., 152, 37-47, 1999.

Wang, J. Y., Fang, X. M., Zhang, W. L., Zan, J. B., and Miao, Y. F.: Magnetostratigraphy and its implications of the Heilinding section, the Linxia Basin, Gansu Province, China, Marine Geology \& Quaternary Geology, 30, 129-135, 2010.

Wang, P. X.: Progress in Late Cenozoic palaeoclimatology of China: a Brief Review, in: The Evolution of the East Asian Environment, edited by: Whyte, R. O., Chiu, T. N., Leung, C. K., and So, C. L., Center of Asian Studies, University of Hong Kong, Hong Kong, 165-187, 1984.

Wang, W. M., Saito, T., and Nakagawa, T.: Palynostratigraphy and climatic implications of Neogene deposits in the Himi area of Toyama Prefecture, Central Japan, Rev. Palaeobot. Palyno., 117, 281-295, 2001.

Wang, W. T., Zhang, P. Z., Kirby, E., Wang, L. H., Zhang, G. L., Zheng, D. W., and Chai, C. Z.: A revised chronology for Tertiary sedimentation in the Sikouzi basin: implications for the tectonic evolution of the northeastern corner of the Tibetan Plateau, Tectonophysics, 505, 100-114, 2011.

Wang, X. M., Wang, B. Y., Qiu, Z. X., Xie, G. P., Xie, J. Y., Downs, W., Qiu, Z. D., and Deng, T.: Danghe area (western Gansu, China) biostratigraphy and implications for depositional history and tectonics of northern Tibetan Plateau, Earth Planet. Sc. Lett., 208, 253-269, 2003.

Wang, X. M., Qiu, Z. D., Li, Q., Wang, B. Y., Qiu, Z. X., Downs, W. R., Xie, G. P., Xie, J. Y., Deng, T., Takeuchi, G. T., Tseng, Z. J., Chang, M., Liu, J., Wang, Y., Biasatti, D., Sun, Z. C., Fang, X. M., and Meng, Q. Q.: Vertebrate paleontology, biostratigra- phy, geochronology, and paleoenvironment of Qaidam Basin in northern Tibetan Plateau, Palaeogeogr. Palaeocl., 254, 363-385, 2007.

Wang, X. X., Zattin, M., Li, J. J., Song, C. H., Peng, T. J., Liu, S. P., and Liu, B.: Eocene to Pliocene exhumation history of the Tianshui-Huicheng region determined by Apatite fission track thermochronology: implications for evolution of the northeastern Tibetan Plateau margin, J. Asina Earth Sci., 42, 97-110, 2011.

Wang, Y. D., Zheng, J. J., Zhang, W. L., Li, S. Y., Liu, X. W., Yang, X., and Liu, Y. H.: Cenozoic uplift of the Tibetan Plateau: Evidence from the tectonic-sedimentary evolution of the western Qaidam Basin, Geoscience Frontiers, 3, 175-187, 2012.

White, J. M., Ager, T. A., Adam, D. P., Leopold, E. B., Liu, G., Jetté, H., and Schweger, C. E.: An 18 million year record of vegetation and climate change in northwestern Canada and Alaska: tectonic and global climatic correlates, Palaeogeogr. Palaeocl., 130, 293306, 1997.

Wu, F. L., Fang, X. M., Mark, H., Mosbrugger, V., and Miao, Y. F.: Extended drought in the interior of Central Asia since the Pliocene reconstructed from sporopollen records, Global Planet. Change, 76, 16-21, 2011.

Wu, F. Y., Huang, B. C., Ye, K., and Fang, A. M.: Collapsed Himalayan-Tibetan orogen and the rising Tibetan Plateau, Acta Petrol. Sin., 24, 1-30, 2008.

Wu, Z. Y.: Vegetation of China, Science Press, Beijing, 1995.

Xia, W. C., Zhang, N., Yuan, X. P., Fan, L. S., and Zhang, B. S.: Cenozoic Qaidam basin, China: a stronger tectonic inversed, extensional rifted basin, Am. Assoc. Pet. Geol. Bull., 85, 715-736, 2001.

Zachos, J. C., Pagani, M., Sloan, L., Thomas, E., and Billups, K.: Trends, rhythms, and aberra 25 tions in global climate $65 \mathrm{Ma}$ to present, Science, 292, 686-693, 2001.

Zachos, J. C., Gerald, R. D., and Richard, E. Z.: An early Cenozoic perspective on greenhouse: warming and carbon-cycle dynamics, Nature, 451, 279-283, 2008.

Zhang, C. F., Wang, Y., Li, Q., Wang, X. M., Deng, T., Tseng, Z. J., Takeuchi, G. T., Xie, G. P., and Xu, Y. F.: Diets and environments of late Cenozoic mammals in the Qaidam Basin, Tibetan Plateau: Evidence from stable isotopes, Earth Planet. Sc. Lett., 333-334, 70-82, 2012.

Zhang, K., Zhao, Y., Yu, Z. C., and Zhou, A. F.: A 2700-year high resolution pollen record of climate change from varved Sugan Lake in the Qaidam Basin, northeastern Tibetan Plateau, Palaeogeogr. Palaeocl., 297, 290-298, 2012.

Zhang, W. L., Appel, E., Fang, X. M., Song, C. H., and Cirpka, O.: Magnetostratigraphy of deep drilling core SG-1 in the western Qaidam Basin (NE Tibetan Plateau) and its tectonic implications, Quaternary Res., 78, 139-148, 2012.

Zhang, W. L., Fang, X. M., Song, C. H., Appel, E., Yan, M. D., and Wang, Y. D.: Late Neogene magnetostratigraphy in the western Qaidam Basin (NE Tibetan Plateau) and its constraints on active tectonic uplift and progressive evolution of growth strata, Tectonophysics, 599, 107-116, 2013.

Zhang, Z. G., Han, W. X., Fang, X. M., Song, C. H., and Li, X. Y.: Late Miocene-Pleistocene aridification of Asian inland revealed by geochemical records of lacustrine-fan delta sediments from the western Tarim Basin, NW China, Palaeogeogr. Palaeocl., 377, 52-61, 2013. 
Zhang, Z. Q. and Sun, J. M.: Palynological evidence for Neogene environmental change in the foreland basin of the southern Tianshan range, northwestern China, Global Planet. Change, 75, 5666, 2011.

Zhang, Z. S. and Guo, Z. T.: Spatial character reconstruction of different periods in 5670 Oligocene and Miocene, Quaternary Sci., 25, 523-530, 2005.

Zhang, Z. S., Wang, H., Guo, Z., and Jiang, D.: What triggers the transition of palaeoenvironmental patterns in China, the Tibetan Plateau uplift or the Paratethys Sea retreat?, Palaeogeogr. Palaeocl., 245, 317-331, 2007.

Zhao, Z. J., Fang, X. M., and Li, J. J.: Paleomagnetic dating of the Jiuquan Gravel in the Hexi Corridor: implication on the midPleistocene uplift of the Qinghai-Tibetan Plateau, Chinese Sci. Bull, 46, 1208-1212, 2001.

Zheng, D. W., Zhang, P. Z., Wan, J. L., Yuan, D. Y., Li, C. Y., Yin, G. M., Zhang, G. L., Wang, Z. C., Min, W., and Chen, J.: Rapid exhumation at $8 \mathrm{Ma}$ on the Liupan Shan thrust fault from apatite fission-track thermochronolgy: implications for growth of the northeastern Tibetan Plateau margin, Earth Planet Sc. Lett., 248, 198-208, 2006.
Zheng, H. B., Powell, C. M., An, Z. S., Zhou, J., and Dong, G. R.: Pliocene uplift of the northern Tibetan Plateau, Geology, 28, 715-718, 2000.

Zhou, J. X., Xu, F. Y., Wang, T. C., Cao, A. F., and Yin, C. M.: Cenozoic deformation history of the Qaidam Basin, NW China: results from cross-section restoration and implications for QinghaiTibet Plateau tectonics, Earth Planet. Sc. Lett., 243, 195-210, 2006.

Zhou, L. H., Sun, S. Z., and Chen, G. C.: Vegetation of Qinghai Province (1:1000 000), China Science and Technology Press, Beijing, 23-24, 1990.

Zhuang, G. S., Hourigan, J. K., Koch, P. L., Ritts, B. D., and KentCorson M. L.: Isotopic constraints on intendified aridity in Central Asia around $12 \mathrm{Ma}$, Earth. Planet. Sc. Lett., 312, 152-163, 2011. 